\title{
The Triviality of the New Innovation and Impact in Archaeology and Beyond
}

\author{
Tim Flohr Sørensen
}

\begin{abstract}
What drives archaeology? Is it new empirical discoveries, new methods or new theory? These factors combined are the fuel of the discipline, is the obvious answer. However, debates and research articles frequently reveal how a perceived need for novelty, originality and impact tends to disentangle this triumvirate of archaeological virtues, giving precedence to one asset over others as the supposed driving force. Focusing on archaeological theory, this article taps into current discussions of the nature of archaeological change, reviewing debates on the formation of archaeological theory, its legitimisation and usefulness. Specifically, I address a recent claim that archaeological theory too readily undermines itself by adopting immature ideas and concepts from other disciplines in an uncritical pursuit of novelty. Finally, I discuss how archaeology may contribute more generally to the formation of theory in the humanities by returning so-called borrowed theory.
\end{abstract}

Keywords: archaeological theory, novelty, impact, borrowing, Object-Oriented Ontology

The Saxo Institute, University of Copenhagen Email: klq302@hum.ku.dk 


\section{Introduction}

When I was a PhD student, a senior colleague gave me a friendly warning. She stated that 'theory, for the sake of theory, is barren'. Despite the simplicity of the advice, and its seeming innocence, it led to a question that has lingered with me ever since: What makes archaeological theory useful? If theory on its own is barren, what does it take to make it worthwhile? I might be grossly generalising, but it seems to me that many archaeologists consider theory useful only when it allows for a better description, understanding or interpretation of the archaeological material under scrutiny, or if it leads to a more plausible explanation of the culture historical trajectories in the past. In this understanding of theory, it is an instrument, part of a research process going from 'data' across 'theory' to 'understanding' (or 'explanation', or 'interpretation'), or a way of seeing archaeological data through a theoretical prism. That is to say, theory is considered useful when in the service of archaeological data. In this article, I want to explore other possible perceptions of theory and theorization in archaeology, examining what happens with theorization and its usefulness if the relationship between data, theory and understanding is reversed, broken or dissolved altogether. By extension, I want to ask whether archaeological theory can be useful for questioning and destabilising theory itself, i.e. whether theory can indeed be useful for the sake of theory.

Obviously, this exploration is by no means new. This is indeed one of the points of this article. As some readers will already have recognised, the basis for this article rests in part on the notion that data is always embedded in a 'cloud of theory' (Johnson 20I0:I06). It may also shine through that the article is stimulated by the notion of 'theory adrift' as coined by Póra Pétursdóttir and Bjørnar Olsen (2018) in their 'morphological' approach to theory as constantly coming together and breaking apart, as well as by the idea of theorization as an 'art of borrowing' (Lucas 2015; Pétursdóttir \& Olsen 20I 8). Also, I am inspired by arguments made recently by Artur Ribeiro (20I6a), contending that archaeology has become too obsessed with novelty for the sake of novelty, forsaking old ideas and concerns regardless of their unrelenting usefulness or need for further improvement. I will argue that we need to 'stay with the trouble' (Haraway 20I6), going 'where everyone has gone before, but where few have bothered to linger' (Bogost 20I2:34). Indeed, the aim of the article is to explore whether it is possible to formulate relevant theorization that is explicitly unoriginal, repetitive and in essence 'old news'. Accordingly, a success criterion for this article is to refrain from doing anything new.

My motivation for writing the article has been repeated conversations, discussions and arguments with colleagues about the general inability of 
archaeology to make an impact on other disciplines and its supposed failure to contribute with something new. These discussions have primarily taken place in the late hours of the evening, and usually in the company of anthropologists. One of them has been particularly adamant in claiming that archaeology is a 'slow burner', contending that the discipline only begins paying attention to theoretical discussions, philosophical concepts and social models about a decade after they were in vogue in anthropology. Uncomfortably reminded of the allegation that 'archeologists have strong backs and weak minds' (Flannery I982:267), my counter-argument tends to be that archaeology is an eclectic discipline, never too proud to import yesterday's theory, models, concepts or tools if they contribute to archaeological knowledge production (see also Ion 20I7; Lucas 2015).

Yet I also have to admit that archaeology is not just eclectic; it is also parasitical (compare with Pétursdóttir \& Olsen 2018:99). Historically, archaeology has failed to make significant epistemological contributions with purchase outside of its own field, remaining a consumer of theories and concepts from other disciplines without returning the favour: archaeology has not contributed to the production of theory in the humanities more generally (see also Lucas 2015:23-24). Even central modes of thinking in archaeology - through stratigraphy, typology, seriation and various social models - derive from other disciplines: geology, biology and anthropology. While archaeologists readily look to these disciplines, as well as chemistry, sociology, comparative religion, genetics, philosophy, computer science, literary studies, economy, cognitive science and human geography for tools and concepts, it seems to me that other disciplines rarely seek inspiration in archaeology, except perhaps as a metaphor. The only archaeological element that has had a partial influence on other disciplines is the notion of 'material culture', a concept that can equally be claimed to originate within other fields of research, for instance anthropology and ethnology.

To archaeologists, the lack of interdisciplinary interest in their discipline may seem strange, perhaps even frustrating. Take for instance Bjørnar Olsen's (2OI 2a) observation that a mammoth publication on Making Things Public (Latour \& Weibel 2005) included contributions by scholars from some ten to fifteen disciplines, yet not a single archaeologist was amongst the contributors, 'despite the fact that no other discipline has done more to make things public' (Olsen 20I2a:72). Yet, whose loss is it, one might ask, when scholars from other discipline fail to take an interest in archaeology? Ours or theirs? Seeking inspiration in other disciplines and adopting their ideas and methods might be unproblematic for archaeology; a discipline accustomed to collaborating intensely with other disciplines, since the dawn of the discipline itself. However, it is perhaps somewhat limiting that ar- 
chaeology does not turn out theory, concepts or methods useful for other disciplines. It is limiting, because some of archaeology's interdisciplinary potential then remains unfulfilled, letting our surroundings 'believe that all we do is study and interpret the past', and that our only relevance is 'in the past' (Nilsson Stutz 20I8:54).

In an interdisciplinary perspective, archaeology may thus have a limited impact by not setting the agenda or defining new directions and 'turns' in the broader academic landscape. Whether this is a problem is of course open for discussion, but it seems that academics generally - but also archaeologists specifically - hold impact, novelty and originality to be important, coming close to constituting the benchmarks for assessing the quality and relevance of research. To some extent, innovation seems to be synonymous with impact. Some go as far as dismissing the work of fellow scholars for failing to be innovative (e.g. Lindstrøm 20I5, 2017; Ribeiro 2016b) or for being reactionary under the guise of innovation (Vander Linden 20I7:I29), and thus redundant or impotent. Torill Christine Lindstrøm (2015) thus rejects the relevance of symmetrical archaeology because she holds it to be 'old wine in new bags', just like Lewis Binford (1988) ridiculed Ian Hodder's Reading the Past for drawing on R.G. Collingwood, whom Binford seemed to consider a dated or inferior historian. Perhaps this is a relatively innocent and standard rhetoric in the academic exercise of criticism, yet at the same time, archaeological work is frequently celebrated precisely when using innovative methods or making new discoveries, attesting to an at least perceived need for innovation, progress and impact. The devotion to novelty furthermore leads to research-funding bodies explicitly defining 'innovation' and 'originality' as indispensable requirements in competitions for grants. Likewise, most peer-reviewed journals with a certain level of self-esteem ask reviewers to assess whether the manuscript under evaluation offers an 'original' contribution to the journal by putting a new argument on the table, using new methods or analysing new data. Across the board, being innovative and original is thus a necessity in order to justify research activities, and a means of benchmarking the impact of the resulting scholarship as well as the usefulness of arguments in debates.

Yet, as Ribeiro asks, why is innovation considered indispensable for making good, relevant research, when archaeology is replete with objects, sites and monuments, and with topics and methods, in need of further exploration and development? Why have innovation and originality become unquestioned prerequisites for contributing to the state of the art in one's field of research? By extension, it also seems necessary to ask whether innovation and originality are essential in order to formulating relevant archaeological theory. Is it necessary to define a new agenda every decade, 
or to align with the slipstream of the most recently hyped 'turn' in anthropology, human geography, philosophy, literary studies or aesthetics? Are there no alternatives to the innovation craze?

Altogether, in this article I will look at the perceived need for innovation in archaeology from two - perhaps paradoxical - perspectives at once: I am concerned that archaeology becomes obsessed with novelty for the sake of novelty, and at the same time I am troubled by the general incapacity of the discipline to contribute to theorization in the humanities. First, I will visit some recent discussions of the obsession with the 'new' in archaeology. I will then debate the relationship between novelty and theory, and subsequently move on to considering what defines theory in archaeology and, in turn, its adoption of ideas from other disciplines. This leads me to focus on the recent embrace of Object-Oriented Ontology as an example of theoretical borrowing in archaeology. Eventually, I argue that the ultimate challenge for archaeological theorization lies in the capacity to adapt, rework and return borrowed concepts to other disciplines.

\section{The tyranny of innovation}

Recently, Ribeiro (2016a) questioned the widespread compulsion for revolutionizing archaeology and the perceived need to constantly adding something 'new' regardless of quality and purpose. As he contends, 'ideas are considered valid as long as they are original' (Ribeiro 20I6a:I46), whereby the 'new' and 'original' assumes an exclusive status in a blind quest for 'paradigmatic change'. As a consequence, scholars tend to shelve old ideas, methods, observations and concerns that are somewhat uncritically and automatically considered dated or trivial: 'What seems to matter nowadays is novelty - or at least the illusion of novelty - but not the improvement of old ideas' (Ribeiro 20I6a:150).

While Ribeiro is mainly concerned with this issue in relation to archaeological theory, his critique resonates equally well with requirements made by funding bodies in the application for research grants, as noted above. To elaborate, the European Research Council's funding strategy is to support 'frontier research', encouraging cross-disciplinary research within 'new and emerging fields', inciting projects that 'introduce unconventional and innovative approaches' (European Research Council 20I7). Likewise, the Arts \& Humanities Research Council in the United Kingdom recently defined 'heritage' as one of its priority areas with the aim of developing a strategy for supporting 'the continued development of heritage research as a vibrant, innovative, highly collaborative and cross-disciplinary research field' (Arts and Humanities Research Council 2018). Similar demands are represented 
in a variety of national instruments elsewhere, for instance in the Swedish Starting Grant (under the auspices of the Swedish Foundation for Humanities and Social Sciences), stating that 'the applicants must demonstrate the ground-breaking nature' of their proposed projects (Swedish Foundations' Starting Grant 20I8). Finally, Independent Research Fund Denmark lists several assessment criteria for proposed projects, and amongst these, the application must 'demonstrate the project's potential for scientific progress, innovation and originality'. Furthermore, the project should 'represent innovative research rather than just being an expansion of current research' (Independent Research Fund Denmark 2018). Nowadays, standing on the shoulders of giants is antiquated, it seems.

In all the above-mentioned examples, Ribeiro's critique is on the money; projects worthy of funding are projects that do research in a new key. Yet the funding bodies' application guidelines offer no description of how they define innovation, originality or ground-breaking research, nor do they clarify why these qualities (nor cross-disciplinary research for that matter) are considered necessary or particularly favourable. Perhaps we should assume that the meaning and usefulness of 'innovation' and 'originality' is self-evident. Yet, if 'innovation' and 'originality' are indeed self-evident and obvious necessities, why do the funding bodies have to spell out those very features as particular requirements? By comparison, none of the guidelines require the applicant to avoid plagiarism or strawman arguments, presumably because it should be self-evident that such elements are undesirable. So why specify 'innovation' without defining its characteristics or necessity if it is equally self-evident?

Considering the broader tendency to fixate on the new just for the sake of its newness, Ribeiro's critique is clearly very relevant. The problem is not to be underestimated, because - as Ribeiro argues - crucial and unresolved academic challenges are sometimes disregarded, even abandoned, simply because they go out of style, or because they do not rhyme the hyped buzzword of the day, or with 'whatever is hip and sexy in other disciplines' (Ribeiro 20I6a:I47). Admittedly, there is occasionally something pompous in the labelling of various scholarly discourses, for instance when David Clarke coined a 'New Archaeology' (Clarke 1973), when symmetrical archaeology is being grouped with the 'New Materialisms' (Witmore 20I4), when scientific advances in archaeology are portrayed as a revolutionising 'new chapter in archaeological knowledge' (Kristiansen 20I4:I2), when philosopher Graham Harman defines 'A New Theory of Everything' (Harman 2018a), when anthropologists Amiria Henare, Martin Holbraad and Sari Wastell define an ontological 'breakthrough' (Henare et al. 2007:12-15), or when the Anthropocene is portrayed as 'a shock to the categories of social theory [...] a jolt that forces to the sur- 
face the full significance of technofossils as the trace markers of a distant dead future' (Dibley 2018:46, emphases added). The question is of course what the 'new' signifies in such bombastic vocabulary, at times verging on the bizarre. Is it a mere rhetoric gesture? Does it herald a revolutionising epistemological breakthrough of seismic dimensions, or is the 'new' synonymous with something more modestly 'different', i.e. with making additions rather than instigating ruptures?

Ribeiro is particularly concerned with archaeologists promoting premature or misunderstood theoretical trends from other fields of research on to archaeology under the shroud of self-proclaimed inventiveness. Specifically, he criticises 'archaeological theorists' (Ribeiro 20I6a:I46) for behaving 'like condescending parents who believe they know better', while they try to 'force archaeology into a new fad philosophy or theory', which will eventually turn out to be inadequate (Ribeiro 20I6a:150). Yet according to Ribeiro, the problem is not simply the import of deficient philosophy into archaeology, akin to what Andrew Sherratt calls 'the imposition of inappropriate models from outside its own field' (Sherratt I993:I28; see also Lucas 20I2:I-2). The problem is theory itself, which Ribeiro seems to consider an added, optional element coming after the core of archaeology: fieldwork and data-driven activities. Within the excess space of theory, he claims, theorists are free to scamper about in a wordy and superfluous pursuit of ways to force paradigmatic changes on to archaeology. A very similar critique was formulated by Michael Shanks, some thirty years ago, diagnosing this trend as entirely opportune, 'furthering academic careers through importing the latest fashionable French theory into an academic world and publishing industry which welcomes the advent of a new paradigm, new intellectual fads' (Shanks I990:297). Ribeiro argues that this trend has become an increasing problem over the past decades, where the responsible parties have managed to establish that 'new theories and approaches have the same value as, if not more value than, engaging with the material record and providing new empirical discoveries' (Ribeiro 20I6a:I 47). This resounds a claim made by the 'Old Timer' in Kent Flannery's parable of the Golden Marshalltown, contending that all the trouble started when some (processual) archaeologists "began to think of "archeological theory" as a subdiscipline in its own right - a higher and more prestigious calling than the pursuit of data on prehistory' (Flannery 1982:27I). Theory, the Old Timer continues, 'would be exciting, if they were any good at it. Unfortunately, in most cases, it's the only thing they're worse at than field archeology' (Flannery I982:272).

By the same token, Ribeiro moves on to contrasting archaeological theorists to the practitioners of archaeology: 
These nameless archaeologists are the vast majority and it is these who unconsciously and gradually add more insight into the past. They are the commercial archaeologists, the students of archaeology and the county archaeologists [...] making sure that archaeology is practised in a correct and proper manner. They improve archaeology by adding information to the ever-growing database of archaeological knowledge. Like the wind that gradually erodes the rock, the nameless archaeologists are those who sculpt archaeology into something superior. (Ribeiro 20I6a:I48)

A similar praise for the practitioners of archaeology has recently been voiced by Kristian Kristiansen, expressing the view that archaeological practice, and not theory, propels the discipline. While he considers theory to be moving in predictable oscillations between opposing -isms, most notably processualism and post-processualism (based in respectively Rationalism and Romanticism; see Kristiansen I996, 2008; also Sherratt I989; Sørensen I984), Kristiansen contends that archaeological practice and archaeological science are superior - even insensitive - to such currents. He portrays scientific 'breakthroughs' as capable of 'producing new knowledge that had previously been unobtainable and thereby making former interpretations and theories obsolete' (Kristiansen 20I7:I20). For Kristiansen (2008:I3), theory remains secondary to practice, science and data, since 'new natural-science-based innovations pave the way for new global knowledge and interpretations' - not the other way around. As he expresses it, in seamless alignment with Ribeiro:

Those archaeologists who did not adhere to any of the -isms, which were the majority, carried on their work by increasingly employing archaeological science in fieldwork and accumulated new evidence until an interpretative breaking point was reached. (Kristiansen 20I7:I20)

Here we have the salt of the earth: archaeologists immune to theorization, the practitioners and the no-nonsense field workers, modestly concerned with the 'proper' way of doing archaeology. Accordingly, the meek shall inherit the earth, i.e. the archaeologists submitting themselves to the ungrateful and unheeded drudgery of data accumulation, the tedious processing of evidence and the painstaking application of new scientific methods, ultimately, almost reluctantly, revolutionizing archaeology.

The myth of the humble, hard-working field archaeologist is indeed powerful, and so is the trope of archaeological breakthroughs based on scientific evidence. However, these figures - the field worker and scientific evidence - also rest on what I perceive to be an unwarranted and unworkable compartmentalization of archaeological practice, science and data as distinct from theory. Consider Ribeiro's image of the alternative to the practitioners of archaeology: 
on the other side of the fence there are theorists who insist in new revolutions and proclaim the death of [insert irrelevant theory of the past here], the same theorists who think they can make an even better sculpture by simply borrowing a bulldozer and laying everything behind them to waste. (Ribeiro 20I6a:I48)

Seemingly, cohorts of archaeological 'theorists' (sounding more like 'terrorists' from the description above) merely work to add new buzzwords and engage in fruitless - even destructive - discussions of the works of scholars with a 'French-sounding name' or 'whose name has too many consonants and not enough vowels' (Ribeiro 20I6a:I47). As I see it, the problem is not so much Ribeiro's disdain for 'theorists', but more so two crucial consequences of this aversion: first, the perception that it is possible to separate theory and practice (allowing for the maintenance of clichéd figures like theorists and shovel bums, and the alleged fence between them), and second, the idea that the borrowing of theory is somehow prone to leading to inferior, backsliding or even delusional archaeological theory.

\section{Destabilising theory with Object-Oriented Ontology}

To be specific about the character of borrowed theory, I want to refer to Object-Oriented Ontology (or 'OOO') as a concrete example of a package of ideas from another discipline (philosophy) that is beginning to make its way into archaeology these years (e.g. Edgeworth 20I6; Pétursdóttir 20I7; Pétursdóttir \& Olsen 20I8; Witmore 20I4). I also choose to point to OOO, because Ribeiro takes issue with this particular philosophy and its application in archaeology, using it as an example of the kind of delusional theory resulting from the adoption of new, untested, poor ideas from outside archaeology. In particular, he targets the influx of Harman's version of Speculative Realism and OOO (Ribeiro refers to Harman 2002, 20II), arguing that it is clad in a conceptually immature 'murkiness' that does not lend more credibility to archaeology, but 'diminishes it' (Ribeiro 20I6a:I48). For Ribeiro, this illustrates just how badly things can go, when archaeologists opportunistically turn to inadequate or poor philosophy in their pursuit of new, fashionable theory. He explains I) how OOO is in fact not really Speculative Realism, 2) how there is nothing in common between the philosophers writing under the banner of OOO, and 3) how Harman is incapable of defining what an object is 'in a clear and concise manner' (Ribeiro 20I6a:I48). Given these alleged flaws, Ribeiro deems OOO invalid and entirely irrelevant for archaeology. In the end, the recommendation seems to be that archaeology should restrict itself to adopting those theories that have already 
passed some form of approval within their original disciplinary settings, preventing archaeology from being led astray by borrowing deficient theory.

To explain OOO briefly, this philosophy contends - at least in Harman's account - that there is a dimension of objects that cannot be known, meaning that aspects of them will always remain hidden: we can never fully know objects (Harman 20I6). With reference to Martin Heidegger (I966:55), Harman describes how objects 'withdraw' or 'withhold' something from direct and full recognition (Harman 20I8b:105-I06), which means that the road towards objects is inevitably indirect or oblique (Harman 20I8a:I2). Hence, for Harman, a description, analysis, explanation or interpretation can never 'exhaust' objects, and these ways of approaching objects never lead to a realistic image of what the object is. Regardless whether we describe objects in terms of their components or their effects, or a combination of both, we look past the object, instead explaining, precisely, components and effects, and not the actual object (Harman 20I3). This does not mean that moving towards objects is impossible or futile, only that the road will always remain indirect and never arrive at a complete and exhaustive account:

Just as erotic speech works when composed of hint, allusion, and innuendo rather than of declarative statements and clearly articulated propositions, and just as jokes or magic tricks are easily ruined when each of their steps is explained, thinking is not thinking unless it realizes that its approach to objects can only be oblique. (Harman 20I2:I2)

For this reason, Harman seems, in some publications, to consider art the most reliable suggestion for a medium for this oblique road to objects that are 'accessible only by allusion and seducing us by means of allure' (Harman 20I 2:I2, also Harman forthcoming).

Ribeiro is not alone in targeting $\mathrm{OOO}$ as a particularly unhealthy syndrome in archaeology. Recently, Alexandra Ion (20I8) has similarly been critical of attempts at achieving archaeological insights with the help of OOO. Yet while Ribeiro uses OOO as an example of how poor judgement can be passed by archaeologists (and philosophers, too), Ion goes further and calls out OOO-inspired archaeology as resulting in 'important ethical and political consequences: a fetishization of things, an abandoning of responsibility, and an alienation of humans' (Ion 20I8:192). Moreover, she contends, OOO merely leads to a 'poetic contemplation of things', turning archaeology from 'a powerful reflexive tool with social, cultural and political impact' into 'a lyrical and passive metaphor' (Ion 2018:198). In the end, Ion argues that OOO is incapable of allowing archaeology to qualify its interpretations, instead leading OOO-inspired archaeologists on to a paralysing return to relativism: 
the issues they discuss are a matter of ontology, which leaves theory as a loose concept. However, theories are very much constructions embedded in institutional and culturally defined contexts, and they serve as anchor points for moving the explanation further. If we embrace a relativistic perspective regarding this aspect, I am afraid we open a Pandora's box in which there is no criterion left for determining which interpretation of the material record is more plausible. (Ion 2018:198)

Altogether, when OOO, according to Ribeiro, is unable to define what an object is, and when $\mathrm{OOO}$ recedes into poetic or lyrical relativism, as Ion claims, there appears to be little or no point of reference, no ethical core, and only a chaotic plethora of possibilities. However, it is mistaken to connect $\mathrm{OOO}$ with relativism, because $\mathrm{OOO}$ is not pursuing a 'criterion' for 'determining' the most 'plausible' interpretation, in Ion's vocabulary. As Harman explains in numerous publications (e.g. Harman 2013, 2016, $2018 \mathrm{a}, 20 \mathrm{I} 8 \mathrm{~b})$, OOO contends that it is not possible to exhaust objects by explanation, interpretation or description. Objects - whether a flint dagger, a city, an idea or the Dutch East India company - will always retain an excess; they 'withhold' something that cannot be captured (Harman 20I8b:I06): a withdrawn side or a 'dark matter' beyond our knowledge, even if the object is in plain sight and available to all possible forms of meticulous, technical inquiry. In Harman's version of OOO, the recognition of objects is indeed characterised by a 'murkiness', as Ribeiro argues, and rightfully so, because a 'clear and concise' (Ribeiro 20I6a:I48) definition would be a delusion. The most 'plausible' interpretation of any object is therefore the one capable of sustaining the murkiness. Hence, the incapacity to fully 'know' an object does not amount or lead to relativism, because the 'dark matter' of objects cannot be enlightened or replaced by subjective truths; 'dark matter' remains dark regardless of perspective.

Importantly, this 'darkness' is not to be understood as gloomy, dangerous or depressing, but rather as a dark that 'has the richness of night, of dreams, of passion, of surrender to boundless mystery and possibility' (Solnit 2007:I69). Nevertheless, some might see this inevitable epistemological uncertainty as incapacitating academia, leading to a depressing and 'helpless chaos in an unintelligible world' (Ion 2018:200), producing nothing more than lyrical, passive metaphors (Ion 20I8:I98). Conversely, I consider it a call for a renewed archaeological realism; one which can take the de facto confusion, vagueness, opaqueness and inexhaustibility of the material world seriously by sustaining it methodically as well as in dissemination, allowing us to open 'Pandora's box with all its gifts' (Serres 2007:I7).

This is what makes for a connection between OOO and archaeology. While OOO seems mainly to have been embraced by scholars working 
within the field of contemporary archaeology, there appears to me to be litthe or no reason to exclude OOO from parts of the discipline working with more conventional notions of archaeology. Some may argue that OOO does not help us say anything about the past (e.g. Barrett 20I6; Ion 20I8:I98), but it may certainly help us say something the archaeological record. Archaeology is, for me, a discipline that studies the world through - or with - traces that are inevitable characterised by some degree of absence, fragmentation and vagueness. The discipline has struggled for a couple of centuries to say as much as possible about the past despite these indeterminacies. OOO might open for an acceptance that some aspects of the past are in fact unknowable, which makes it archaeology's mandate to theorize what it means to know something with inescapable uncertainty. In other words, archaeology is not limited to a choice between evidence and silence but may also explore different ways of working with its indeterminate traces.

If $\mathrm{OOO}$ is correct in contending that some aspects of things will forever remain 'dark', and therefore must be approached indirectly, poetry may not be such a poor method, nor standing in opposition to academic accounts of things. The separation of art and academia may even be 'entirely without substance' and 'a mere fabrication of the division of labour' (Adorno 2000:I4O). This is by no means a claim that art should replace academic scholarship, but it does acknowledge that art and academia may complement or permeate one another (e.g. Bailey 20I8; Benjamin 20I 8; Finn 20I4; Lee 20I8; Pearson \& Shanks 200I; Pétursdóttir 20I8a). Most crucially, explicitly sustaining the uncertainty of knowledge - whether through formal academic research or an infusion with art - serves to challenge the arrogance of presuming that we can arrive at absolute archaeological knowledge of the past through the accumulation of evidence, falsification and validation. Archaeology may have a particular need for admitting to and owning up to its inevitably uncertain epistemology, following Carlo Ginzburg's contention that 'historical knowledge is indirect, presumptive, conjectural' (Ginzburg 1989:I06).

In turn, it is also possible to allow the epistemological uncertainty and hence possibilities - to affect the directions and formation of theory. The 'dark matter' allows theory to not be defined with a specific or universal readymade purpose: theory does not have to serve archaeology by scaffolding retrospective explanations nor predictions. Moreover, it is not possible to define in advance what is relevant for its line of reasoning, nor can we necessarily determine what is relevant and what is 'noise' without experimenting with any given theoretical construct borrowed from outside of archaeology.

Pétursdóttir and Olsen (20I8) have recently made an argument for such an 'art of borrowing'. The authors refrain from portraying this take on the 
archaeological as innovative or original, framing it instead as an already established 'tradition' (Pétursdóttir \& Olsen 2018:99) that largely tends to remain unarticulated. The consequence of 'borrowing' theory, if I am correct, is that archaeology may cease looking to other disciplines for 'off-therack' theory and concepts that are applicable to everything and anything in the archaeological record. Instead, theorizing through 'borrowed' and 'unfinished' theory offers the opportunity for archaeology to engage in the moulding of theory, and potentially to add to the framing, understanding and use of theory. Thereby, the relationship between archaeology and other disciplines must become less compartmentalized, while maintaining the strengths marking each trade. In this way, archaeology may precisely explore unfinished concepts and theories from other disciplines, because they need to be adapted to an archaeological framework. In this way, archaeology may add to the formulation of these very concepts and theories. So just as a philosopher might feel estranged from the phenomenology practiced by Christopher Tilley (e.g. I994), because he adapts it to particular archaeological needs, Pétursdóttir and Olsen (20I8), and Pétursdóttir (20I8b) in particular, argue for an archaeological rethinking of the version of $\mathrm{OOO}$ formulated by Harman rather than simply buying into a readymade and monolithic theoretical instrument (see also Lucas 2015:15). In summary, this way of thinking with OOO in archaeology falls somewhat short of simply adopting a 'new fad theory', because the ways in which Pétursdóttir and Olsen make use of OOO is not blindly loyal to the original. Rather, they stay close to archaeological matter, and reformulate the borrowed philosophy to their own uses. Hence, welcoming ideas from OOO into archaeology does not serve the purpose of revolutionising archaeology but opens a different attitude to the archaeological.

Consequently, Pétursdóttir and Olsen (20I8) argue that theory and practice, or perhaps rather 'theory-things-method', are essentially entwined. Gavin Lucas (e.g. 20I2) and Matt Edgeworth (20I2) express similar views by evening out the actual relationship between theory and practice, demonstrating how even the most craftsman-like fieldwork can at least be and most often is - stimulated by and stimulating theorization, and vice versa. Pétursdóttir illustrates this flattening of theory and practice eloquently in her study of sub-Arctic drift matter (Pétursdóttir 2017, 2018a), stating explicitly that she does 'not discriminate between theory, practice and "data", between ontology and epistemology, or between matter and meaning' (Pétursdóttir 2018b:207; see also Garcia-Rovira 2015:93). The consequences are (at least) twofold: first, theory is integral to the practice of archaeology and vice versa; and second, theory is essentially mobile (Lucas 20I5), or 'adrift' (Pétursdóttir \& Olsen 20I8). Thus, considering theory inseparable from practice and the material makes theory as restless and un- 
ruly as archaeological formation processes and archaeological fieldwork, and hence chronically unstable.

\section{Mobilising the archaeological}

In this perspective, it becomes difficult - in my opinion - to ever speak of a stabilization of theory into something akin to 'models' or 'hypotheses', which are epistemological phenomena of a different order. Phrased axiomatically, a hypothesis describes an assumption about certain facts, explanations or regularities, whose validity must be tested and proven. Thereby, a hypothesis comes before data. A model, in turn, is a schematic description or illustration of an abstract or complex phenomenon, causality or a set of relations. In this sense, a model comes after data. Altogether, in the words of David Clarke, 'Models and hypotheses succeed in simplifying complex situations by ignoring information outside their frame of reference and by accurate generalizing about it' (Clarke I978:3 I). Explanatory models thus 'represent specific factors, variables or processes presumed to constitute the archaeological target, whether this is a particular event, a local set of practices, or large-scale cultural systems and long-term processes' (Wylie 20I7:I000). Theory, I suggest, offers a more loosely defined framework for continuous reflection through data (see also Malmer 1997:9). Theory can never be a means of proving or dismissing an allegation but constitutes a prism for critique. As such, it makes no sense to speak of ' $a$ theory', but only of 'theory', or perhaps even better of 'theorization', emphasising it as an ongoing practice. While hypotheses and models can be defined, refined and replaced in discrete actions and reactions, theory will remain forever mutable without a stable core (compare with Sherratt I993, who argues conversely that archaeology should strive for 'theoretical coherence'). ${ }^{\mathrm{I}}$

The formal history of archaeological theory is perhaps guilty of betraying its own organic nature; first by using the monolithic epithet 'theory' and second by tending to narrate the history of archaeological theory like a culture-historical waxing and waning of conceptually coherent hegemonies. The term 'theory' perhaps also suggests, wrongly, that there is something stable and unified about it, and that theory is distinct from 'method', 'practice' or 'data' (see also Hodder I992:I49-I5O). By extension, it is mistaken to think of processualism and post-processualism as two different 'theories'. Theory is rather what unites processualism and post-processualism, while their description as distinct 'paradigms' portray them as discrete con-

I I do not distinguish between 'archaeological theory' and 'theoretical archaeology' (e.g. Gramsch 20II). 
ceptual models that one can choose between, and which replace each another. Indeed, 'theory does not die, it changes direction' (Kristiansen 20I I), but according to Oliver Harris and Craig Cipolla (20I7:28), archaeology has never gone through any paradigmatic change. Rather, they argue that the discipline has merely been oscillating between different stances on the same dualistic, Cartesian paradigm. Part of the reason for the confusion of 'theories' with 'paradigms' may rest on a 'theoretical sloppiness' (Lucas 20I7:267), leading Lucas to ask whether the paradigm concept might be replaced by notions of the 'exemplar' or the 'template' (Lucas 2017:267). Yet, if the grand narrative of archaeological theory is guilty of delineating monolithic 'theories', thereby conflating 'theory', 'model' and 'hypothesis', as well as 'theory' and 'paradigm', it also fails to do justice to the more organic forms of theorization that have actually been issuing forth within the discipline. Perhaps the history of archaeological thinking ought to be narrated as travelling without any paradigmatic bearing, instead going in multiple directions at once.

A possible resolution to the confusion of theory, models, hypotheses and paradigms might be to opt for a term like 'theorization' instead of 'theory', indicating an activity or practice rather than conceptual object, and hence something mobile instead of something stable (see also Kristiansen 20II; Lucas 20I5; Pétursdóttir \& Olsen 20I8). The point with such terminological reorientation is not simply to use the terms more accurately, but also to avoid giving the impression that 'theories' develop into monolithic discourses along the lines of a linear, evolutionary progression, becoming obsolete and replacing one another. Pétursdóttir and Olsen (2018) offer the image that theory (in the infinite) is 'adrift' and come together and break apart in non-linear movements consistent with the sea-borne debris they encounter on the shores of the North Atlantic. Moreover, they refer to Harman's (20I6) recent discussion of the Dutch East India Company (VOC) as a way to understand what an object is, yet they ask how a particularly archaeological approach to the tactile components of the VOC would look. In this, they call for a study that rests not merely on historical sources, but equally including 'wrecked and sunken ships, released ballast, deserted harbours, distributed goods and derelict fortresses' (Pétursdóttir \& Olsen 20I8:IOI). They imply that a concern for derelict and abandoned things would have resulted in a 'somewhat different conception of objects and object careers' (Pétursdóttir \& Olsen 20I8:IOI). In the context of the Anthropocene, Pétursdóttir (20I7) furthermore explores how OOO may cast light on sub-Arctic sea-borne debris, yet she concludes that ' $\mathrm{OOO}$ is to me far less illuminating about the nature of this material than the material is informative of the potency of OOO' (Pétursdóttir 20I8b:208). Hence, theory depends on the material, forming in accordance with the material, 
which thereby becomes a vehicle for theorization. As a consequence, archaeological theory is not a separate discourse distinct from method and material (Gramsch 20II:63).

In keeping with the entanglement of theory, data and method, Pétursdóttir and Olsen (2018:105) borrow Kathleen Stewart's 'weak theory' (Stewart 2008), where she follows the material intuitively and its own conditions. For instance, Stewart refers to the compiling of 'insane collections' (Stewart 1996:44) of stuff in peoples' backyards; conglomerates of things that are put together simply to 'see what would happen' (Stewart 2008:75). The 'weak' approach allows for observations that would not in advance be considered relevant, setting the researcher free to drift along, conditioned by how things emerge. In this way, the field and matter steer the orientation of the research process, compelling the researcher to see distractions as directions. The 'weak' approach thus contrasts a 'strong' research design that carefully plans data collection and analysis in order to eliminate error in the research process, implying that the 'strong' approach is also a 'paranoid' approach (Stewart 2008:72). Conversely, 'weak' theorization may not always have a distinct and clear purpose or direction but can be conducted just to 'see what happens'. This may issue forth when 'unfinished' ideas from other disciplines are introduced to archaeology, or when 'objects' are defined from a different perspective, or when the archaeological 'record' is rephrased with a different vocabulary (compare with Ribeiro 20I6a:I49). Also, the archaeological encounter with objects in sometimes unexpected contexts, constellations and places may equally stir theorization that leads to questioning and wondering without the anticipation of a distinct bearing or purpose. This does not turn archaeology into something revolutionising new, but it may broaden and destabilise what archaeologists consider knowable about the archaeological or how to approach it.

This brings me back to Ribeiro's notion that 'theorists' are obsessed with the new, while slow-grinding field archaeologists accumulate 'information to the ever-growing database of archaeological knowledge' without concern for the spectacle of novelty or originality: 'archaeology undergoes continuous revisionary changes in an undramatic way' (Ribeiro 20I6a:I50). Yet if theory should be considered 'adrift' it will necessarily also imply the reappearance of old ideas and concerns, characterising attempts at revisiting many of the concerns that have occupied archaeologists since the emergence of the discipline. In this perspective, the 'theorists' may perhaps not - contrary to what Ribeiro claims - be so concerned about revolutionising archaeology or defining a 'new' trend at any given time: actually, they may 'merely' explore different perspectives on the same old problems. For instance, in a collective volume by Bjørnar Olsen, Michael Shanks, Chris Witmore and Christopher Webmoor, the authors declare: 'What is needed 
today is an archaeology that looks back at its own past with neither embarrassment nor contempt, but with wonderment combined with the will to revitalize its important legacy' (Olsen et al. 20I2:197). Similarly, in a response to critics, who were worried that his arguments resounded 'oldfashioned empiricist archaeology', Olsen declares: 'I am not so worried, since I actually think there is a lot to be learnt from the material sensibility characterizing this archaeology, and that the challenge is not to abolish this sensibility but rather to develop it further' (Olsen 20r 2b:98). Here we find no delusional or grandiose claim about spearheading radical redirections of archaeology, but rather a desire to reinvigorate aspects of archaeology that prematurely ran out of fashion or turned out to be neglected. Also outside of archaeology, Jane Bennett, whose name is often connected with New Materialism, argues that what her concept of 'vital materialism' brings to the table is not 'radically new, but part ad hoc invention and part a gathering of elements from preexisting traditions' (Bennett 20I0:47).

This all boils down to a question of defining 'novelty' and 'innovation'. Perhaps I have been as guilty as the funding bodies, I mentioned in the beginning of the article, of failing to properly describe what I associate with these terms. I have expressed a sense of tiredness with the perceived necessity for innovation and revolutionizing discoveries amongst research granting institutions, academic journals and in the competition between colleagues. Perhaps much can be achieved by simply cooling the rhetoric, becoming more modest about what is implied by the terms 'novelty' and 'innovation' in archaeology. In a sense, I speak in favour of a kind of 'slow academia', less concerned with making so-called 'ground-breaking' discoveries, coining revolutionising 'turns', devising game-changing methods or obsessed with making headlines in mainstream media and academic journals. Effectively, oftentimes what is portrayed as 'pioneering', 'cutting-edge' and 'groundbreaking' seems to me to be more about formulating subtle redirections and variations, and adding details than about making truly breath-taking discoveries and dramatic epistemic ruptures. And there is nothing wrong in that. It only implies that rethinking existing ideas and revisiting old ones in sometimes unplanned, counterintuitive and experimental ways may qualify as a form of 'patient novelty', accepting that each of the elements combined are well-known and perhaps even consider by some as 'dated'.

Accordingly, by borrowing theory, old ideas as well as ideas from other disciplines are allowed to be unfinished and may remain so, lending themselves to further theorization through encounters with fieldwork, things and practice (Pétursdóttir \& Olsen 20I8:IO2). As I see it, borrowing is not only the 'art of keeping theory alive' (Pétursdóttir \& Olsen 20I8:II5), it is also the potential for archaeology to return the favour with appropriate dues, precisely by seeing fieldwork, practice and the archaeological record 
as matter for theorization. Hence, by attending to the material in the development of philosophical, anthropological and other discourses on matter, archaeology may contribute with a different form of 'material theorization'. Importantly, this implies that objects are not reduced to mere illustrative examples of something other than themselves, for instance by referring to a generic hammer (Heidegger 1962:\$I5), a generic stone (Ingold 2007) or a generic table (Harman 20I2). Rather, archaeology contributes to other disciplines by taking things seriously, as it always has, literally seeing objects as the very (dark) matter for theorization. ${ }^{2}$

At this point I have to realise that I end up in a bit of a pickle: I argue, simultaneously, that objects should be used for theorization and that archaeological material, practice and theory cannot be separated. How can theory be a prism for looking at the material if theory is indistinguishable from the very material? Furthermore, if theory is embedded in all archaeological practice, how does it make sense to speak of 'theorization' as a particular endeavour? Possibly, the solution is to jettison the notion of 'theory' altogether (along with 'material' and 'practice') and stop worrying whether thinking belongs to one domain or another. Whether I am ready to take that step myself, I am not sure.

\section{Returning the favour: Towards material philosophy}

When my colleague stated that 'theory, for the sake of theory, is barren', I soon gathered that the subtext was, first, that theory can indeed be distinguished from data, and, second, that data, for the sake of data, would never be barren. In this view, theory can only be justified by its usefulness for data. Or, in the words of Bruce Trigger, 'Instead of developing theory for its own sake [...], archaeologists should seek to craft theories that are appropriate for their own database and the analytical methods they can hope to devise for examining them' (Trigger 2006:518). Conversely, I contend that theorization can be worthwhile in its own right as a way of generating contributions to the humanities more broadly (compare with Binford I962).

Now, some readers may have experienced a sense of déjà $v u$, reading these pages, reminiscent of the exchange between the 'Old Timer', the

2 It may seem paradoxical that I argue for letting things drive theorisation without including empirical material in the article (apart from letting OOO constitute my object of study). However, I contend that the exchange between things and theory need not be present in every single publication, nor do I believe that the mechanical use of examples serves the point. Accordingly, I refer to other publications, where I have spent time on things, such as burial practices, cemeteries and ruins, as the material ground for the kind of theorisation presented in this article. 
'Born-Again Philosopher' and the 'Child of the Seventies' in Flannery's parable of the Golden Marshalltown (Flannery 1982). The Born-Again Philosopher argues that he has no need for archaeological fieldwork, and certainly no time for contract archaeology; he does not want to remain a mere 'law consumer', aiming instead at being a 'law producer', since the important questions lie on a 'higher level of abstraction' (Flannery 1982:269). Conversely, the Old Timer argues that it is the contract archaeologists who 'deal directly with what happened in prehistory' (Flannery 1982:269). Then there is the Child of the Seventies, who 'could turn out a book a year, using the original ideas of others, without ever having an original idea' (Flannery I982:266). Of course, these figures were caricatures in I982, and they still are today, but it is perhaps worthwhile pondering whether a parable for the archaeology the $2010 \mathrm{~s}$, or the 2020 s, would look so different in comparison with the one for the I980s. Or, rather, a parable might still be possible along the lines of the same caricatures, but I doubt that they ever really existed. Do field archaeologists with a determined focus on the archaeological record never reflect theoretically on the archaeological? Does an archaeologist eager to refine methods for excavating pits never wonder about the culture-historical context? Do the alleged 'theorists' never spend time getting their hands (and minds) dirty in the field?

This brings me to a figure that is oddly understated - taken for granted it seems - in the parable of the Golden Marshalltown as well as absent amongst the archaeological characters praised by Ribeiro and Kristiansen (but see Clarke 1973): the university lecturer and the instructors of archaeology. Ribeiro rightfully mentions students as members of the modest crew invisibly improving archaeology, but I think it is worth noticing and emphasising the people educating these very students. Since academic learning is partially self-taught and partially instruction-dependent, educators, lecturers and supervisors remain an important part of the shaping of the archaeology of the future. Regardless whether this training is reactionary or steeped in the innovation craze, lecturers are co-responsible for the ways in which students are taught to make sense of the relationship between things, method and theory, between archaeological practice and theorization, between archaeology as an academic craft and its relations with the wider community. Academic instructors have the potential for inspiring ideas based on new and old virtues, and for teaching students about the value of 'staying with the trouble' as well as pushing for new possibilities in archaeology. If I were to single out one domain of archaeology as the one leading the way forward, I would have to point not to 'theorists' (as if they exist as a discrete category of archaeologists) or field workers or scientists, nor to the authors of the grand narratives of archaeology (whether in terms of culture-historical trajectories or the history of the discipline). 
I would have to point to the teachers of archaeology, who do not have the luxury of disentangling all these salient faculties when educating the next generation of archaeologists.

I opened this article by asking what drives archaeology; what makes archaeology move as a discipline. Perhaps the crucial question turns out to be, where is archaeology going? In The Golden Marshalltown, the Old Timer asks the narrator of the story the same question. His response is that it 'is sort of drifting, like a rudderless ship. I have the feeling it could fragment into a dozen lesser disciplines, with everybody going his own way' (Flannery 1982:274). The same kind of tendency towards fragmentation might characterise archaeology today with some specializations becoming increasingly dependent on a scientific research design, with others aligning themselves with the currents of theory in the humanities, and then the alleged majority of archaeologists, silently grinding on with their fieldwork at local museums and in contract archaeology. If archaeology is becoming 'hopelessly amorphous' (as once stated about geography; see Last 2018:197), I worry that the discipline will be compromised, because the fragmentation can revitalise unhelpful antagonisms, like the one characterising processual and post-processual discourses in the I980s as well as the alienation of archaeologists from each other's concerns and motivations (compare with Bradley 1993). While I contend that archaeology does not have one single purpose or project, I do wonder whether the potential fragmentation will result is an increasing lack of interest and respect across the diversity of the discipline; a diversity which ought to 'ensure the vitality of the discipline' (Hodder 20I 2:4).

On the other hand, I am not so sure that a 'drifting', 'rudderless' bearing is a problem for archaeology. One might fear that such a course will end in the mooring of the discipline, but it may also take us to seas and shores we could never have planned for. In my opinion, this is precisely the potential of an OOO-inspired archaeology: it allows for a mutual co-dependence or a continuum of theory-things-method without a predefined orientation. In practice, this dependence does not have to issue forth as an explicit and scrupulous balancing of its individual elements, because the implicated parts may not be distinguishable at all. So, while some would probably read this article as 'theoretical' (and hence possibly finding it 'barren'), my point is instead to argue for seeing the continuum of theory-things-method as a strangely elegant mess and not as distinct and discrete operations. I am not saying that things determine theory or method, nor do I claim the opposite; I see no need for prescribing a causal direction in the relationship between theory, things and method, because they can emerge unexpectedly or be nurtured with the purpose of seeing what happens. This also implies that the justification of theory is not its usefulness in explaining or 
understanding data, at least no more than the only usefulness of data is to stimulate theorization.

My argument is that things will always stimulate theorization, and that things are perceived and recognised on the basis of theorization, simultaneously. This view might represent a reactionary archaeology, perhaps even an antiquated fetishization of things as harbouring a force in their own right by their capacity to engender thinking. I admit to this reactionary view, which also means that I find it easy to connect with the large segments of the archaeological environment that respond to new 'discoveries' with almost uncontrolled, fetishist arousal. However, I want to question the very trope of archaeological 'discovery' - whether in the form of a 'new' object, site or scientific result - and the common perception that the unearthing of 'new' things is what makes archaeology move. Frequently taken to imply a sense of disciplinary progress, such discoveries indicate that archaeological data is a necessity, while theorization is superfluous. New 'findings' - whether in the field or the laboratory - have become synonymous with novelty and the possibility for disciplinary progress (a different kind of fetishization, I guess). Hence, the 'discovery', and by extension the culture-historical explanation drawn from the empirical discovery, may even be perceived as the archaeological contribution and the very purpose and legitimisation of the discipline. As the Old Timer declares: 'what the world wants is for archeology to teach it something about humanity's past. The world doesn't want epistemology from us [...] if the world wants philosophy, it will surely turn to philosophers, not archeologists, to get it' (Flannery I982:272). Similarly, Ion argues that the very role of archaeology is to contribute to understanding 'the historical conditions in which certain ontological views have been enacted'; it is not to reflect on the actual ontological matters, she states, because that is the task of philosophy (Ion 20I8:200). In other words: cobbler, stick to your last!

Yet, do we really need to keep up these disciplinary boundaries, I wonder? Why pose such strict limits for what archaeology should and should not do as a discipline? At a time when inter-disciplinary research and any form of collaboration with other disciplines, typically the sciences, are praised ad nauseam, I wonder why archaeology should not tap into, contribute to or seek to generate philosophical insights. Perhaps the borrowing of unfinished, half-baked theory from other disciplines is particularly relevant in this regard, because it allows archaeology to shape theorization and contribute to defining how the humanities might be thinking about old as well as urgent matters. In fact, archaeology might return the favour by contributing with a material perspective on theory from other fields, asking how the material dimension affects theorization, thereby continuing to develop archaeology as a material philosophy. 


\section{Acknowledgements}

Emphasising academic educators as those shaping the future of archaeology, I wish to thank my own teachers for formative experiences through education, conversations, inspiration, challenges, provocations and slaps across the fingers: David Austin, Geoff Emberling, Andrew Fleming, Bo Dahl Hermansen, Stephen Lumsden, Anne-Louise Sommer, Marie Louise Stig Sørensen, Helle Vandkilde and Lyn Wadley. Obviously, the mentors are not to blame for the sins of the offspring. Finally, conversations and discussions with students at the University of Copenhagen have helped me rethink the arguments in this article, just as I have benefitted from succinct and careful critique by two anonymous peer reviewers, and not least by Juliane Wammen.

\section{References}

Adorno, T. 2000. Metaphysics: Concepts and Problems. First published 1965. Translated by Jephcott, E. Stanford (CA): Stanford University Press.

Arts and Humanities Research Council. 2018. Heritage Research. https://ahrc.ukri.org/ innovation/heritage-research/ [Accessed 16 July 2018].

Bailey, D. 201 8. Breaking the Surface: An Artlarchaeology of Prehistoric Architecture. Oxford: Oxford University Press.

Barrett, J.C. 20I6. The New Antiquarianism? Antiquity. Vol. 90 pp. I68I-I686.

Benjamin, J. 20I8. Human-Plant Mutualism in the Built Environment. Pinsapo Journal. Vol. 2 pp. 32-40.

Bennett, J. 20I0. A Vitalist Stopover on the Way to a New Materialism. In: Coole, D.H. \& Frost, S. (eds). New Materialisms: Ontology, Agency, and Politics, pp. 47-69. Durham (NC): Duke University Press.

Binford, L.R. 1962. Archaeology as Anthropology. American Antiquity. Vol. 28 pp. 217225.

Binford, L.R. 1988. Review of Reading the past: Current Approaches to Interpretation in Archaeology by Ian Hodder. American Antiquity. Vol. 53 pp. 875-876.

Bogost, I. 20I2. Alien Phenomenology, Or, What It's Like to be a Thing. Minneapolis: University of Minnesota Press.

Bradley, R. I993. Archaeology: The Loss of Nerve. In: Yoffee, N. \& Sherratt, A. (eds). Archaeological Theory: Who Sets the Agenda?, pp. I3I-I33. Cambridge: Cambridge University Press.

Clarke, D.L. 1973. Archaeology: The Loss of Innocence. Antiquity. Vol. 47 pp. 6-I8.

Clarke, D.L. 1978. Analytical Archaeology. London: Methuen.

Dibley, B. 2018. The Technofossil: A Memento Mori. Journal of Contemporary Archaeology. Vol. 5 pp. 44-52.

Edgeworth, M. 20I 2. Follow the Cut, Follow the Rhythm, Follow the Material. Norwegian Archaeological Review. Vol. 45 pp. 76-92. 
Edgeworth, M. 20I6. Grounded objects: Archaeology and speculative realism. Archaeological Dialogues. Vol. 23 pp. 93-II3.

European Research Council. 20I7. ERC Grant Schemes. https://publications.europa.eu/en/ publication-detail/-/publication/eredoc6b-d97 I-I Ie7-a506-oraa75ed7Iar/languageen/format-PDF/source-92247282 [Accessed 3 April 2019].

Finn, C. 20I4. Home: An Installation for Living In. In: Russell, A.I. \& Cochrane, M.A. (eds). Art and Archaeology: Collaborations, Conversations, Criticisms, pp. II5-I27. New York: Springer.

Flannery, K. 1982. The Golden Marshalltown: A Parable for the Archeology of the I980s. American Anthropologist. Vol. 84 pp. 265-278.

Garcia-Rovira, I. 2015. What About Us? On Archaeological Objects (or the Objects of Archaeology). Current Swedish Archaeology. Vol. 23 pp. 85-108.

Ginzburg, C. 1989. Clues, Myths, and the Historical Method. Translated by Tedeschi, A. C. \& Tedeschi, J. Baltimore: Johns Hopkins University Press.

Gramsch, A. 20I . Theory in Central European Archaeology: Dead or alive? In: Bintliff, J. \& Pearce, M. (eds). The Death of Archaeological Theory?, pp. 49-7I. Oxford: Oxbow Books.

Haraway, D. 20I6. Staying with the Trouble: Making Kin in the Chthulucene. Durham: Duke University Press.

Harman, G. 2002. Tool-Being: Heidegger and the Metaphysics of Objects. Peru (IL): Open Court.

Harman, G. 20I I. The Quadruple Object. Winchester: Zero Books.

Harman, G. 2or 2. The Third Table. In: Christov-Bakargiev, C. (ed.). The Book of Books, pp. 4-I5. Ostfildern: Hatja Cantz.

Harman, G. 20I3. Undermining, Overmining, and Duomining: A Critique. In: Sutela, J. (ed.). Add Metaphysics, pp. 40-5 I. Espoo: Aalto University.

Harman, G. 20I6. Immaterialism: Objects and Social Theory. Cambridge: Polity Press.

Harman, G. 20I8a. Object-Oriented Ontology: A New Theory of Everything. London: Pelican Books.

Harman, G. 2018b. Speculative Realism: An introduction. Cambridge: Polity Press.

Harman, G. Forthcoming. Art and Objects. Cambridge: Polity Press.

Harris, O.J.T. \& Cipolla, C. 20I7. Archaeological Theory in the New Millennium: Introducing Current Perspectives. London: Routledge.

Heidegger, M. 1962. Being and Time. First published 1927. Translated by Macquarrie, J. \& Robinson, E. New York: Harper and Row.

Heidegger, M. 1966. Discourse on Thinking. Translated by Anderson, J.M. \& Freund, E. H. New York: Harper \& Row.

Henare, A., Holbraad, M. \& Wastell, S. 2007. Introduction: Thinking Through Things. In: Henare, A., Holbraad, M. \& Wastell, S. (eds). Thinking Through Things: Theorising Artefacts Ethnographically, pp. I-3 I. London: Routledge.

Hodder, I. I992. Theory and Practice in Archaeology. London: Routledge.

Hodder, I. 20I 2. Introduction: Contemporary Theoretical Debate. In: Hodder, I. (ed.). Archaeological Theory Today, pp. I-I4. Cambridge: Polity Press.

Independent Research Fund Denmark. 2018. Call for Proposals: Autumn 2017 and Spring 2018. https://dff.dk/en/application/calls/call-autumn-2017-and-spring-2018_updated _16-1-2018.pdf [Accessed 3 April 2019]. 
Ingold, T. 2007. Materials against Materiality. Archaeological Dialogues. Vol. I4 pp. I-ı6. Ion, A. 20I7. How Interdisciplinary is Interdisciplinarity? Revisiting the Impact of aDNA Research for the Archaeology of Human Remains. Current Swedish Archaeology. Vol. 25 pp. I77-I98.

Ion, A. 20r8. A Taphonomy of a Dark Anthropocene: A Response to Póra Pétursdóttir's OOO Inspired 'Archaeology and Anthropocene'. Archaeological Dialogues. Vol. 25 pp. I9I-203.

Johnson, M.H. 20I0. Archaeological Theory: An Introduction. Oxford: Blackwell.

Kristiansen, K. 1996. Old Boundaries and New Frontiers: Reflections on the Identity of Archaeology. Current Swedish Archaeology. Vol. 4 pp. I03-I 22.

Kristiansen, K. 2008. Do we need the 'archaeology of Europe'? Archaeological Dialogues. Vol. I5 pp. 5-25.

Kristiansen, K. 20I . Theory does not Die it Changes Direction. In: Bintliff, J. \& Pearce, M. (eds). The Death of Archaeological Theory?, pp. 72-80. Oxford: Oxbow.

Kristiansen, K. 20I 4. Towards a New Paradigm? The Third Science Revolution and its Possible Consequences in Archaeology. Current Swedish Archaeology. Vol. 22 pp. I I-34.

Kristiansen, K. 20I7. The Nature of Archaeological Knowledge and Its Ontological Turns. Norwegian Archaeological Review. Vol. 50 pp. I20-I23.

Last, A. 20I8. Of Interdisciplinarity. In: Lury, C., Fensham, R., Heller-Nicholas, A., Lammes, S., Last, A., Michael, M. \& Uprichard, E. (eds). Routledge Handbook of Interdisciplinary Research Methods, pp. 197-208. London: Routledge.

Latour, B. \& Weibel, P. 2005. Making Things Public. Cambridge (MA): MIT Press.

Lee, D. 20I8. Experimental Mapping in Archaeology: Process, Practice and Archaeologies of the Moment. In: Gillings, M., Haciguzeller, P. \& Lock, G. (eds). Re-Mapping Archaeology: Critical Perspectives, Alternative Mappings, pp. I43-I76. Oxon: Routledge.

Lindstrøm, T.C. 2015. Agency 'in itself': A Discussion of Inanimate, Animal and Human Agency. Archaeological Dialogues. Vol. 22 pp. 207-238.

Lindstrøm, T.C. 20I7. Agency: A Response to Sørensen and Ribeiro. Archaeological Dialogues. Vol. 24 pp. I09-II6.

Lucas, G. 20I2. Understanding the Archaeological Record. Cambridge: Cambridge University Press.

Lucas, G. 2015. The Mobility of Theory. Current Swedish Archaeology. Vol. 23 pp. 13-32.

Lucas, G. 20I7. The Paradigm Concept in Archaeology. World Archaeology. Vol. 49 pp. 260-270.

Malmer, M.P. I997. On Objectivity and Actualism in Archaeology. Current Swedish Archaeology. Vol. 5 pp. 7-I 8.

Nilsson Stutz, L. 20r8. A Future for Archaeology: In Defense of an Intellectually Engaged, Collaborative and Confident Archaeology. Norwegian Archaeological Review. Vol. 5I pp. 48-56.

Olsen, B. 20I2ba. The Return of Things and the Savagery of the Archaeological Object. In: Pereira, G. (ed.). Savage Objects, pp. 7 I-83. Lissabon: Imprensa Nacional-Casa da Moeda.

Olsen, B. 20I2b. Archaeological Theory, Christmas Pork and Red Herrings: Reply to Comments. Current Swedish Archaeology. Vol. 20 pp. 95-106.

Olsen, B., Shanks, M., Webmoor, T. \& Witmore, C.L. 20I 2. Archaeology: The Discipline of Things. Berkeley: University of California Press. 
Pearson, M. \& Shanks, M. 200I. Theatre/Archaeology. London: Routledge.

Pétursdóttir, P. 20I7. Climate change? Archaeology and Anthropocene. Archaeological Dialogues. Vol. 24 pp. 175-205.

Pétursdóttir, P. 20ı 8a. Drift. In: Birch, S.E.P. (ed.). Multispecies archaeology, pp. 85-гог. London: Routledge.

Pétursdóttir, P. 20I8b. Lyrics for a Duskier Enlightenment: In Response to Alexandra Ion. Archaeological Dialogues. Vol. 25 pp. 205-2I3.

Pétursdóttir, P. \& Olsen, B. 20I8. Theory Adrift: The Matter of Archaeological Theorizing. Journal of Social Archaeology. Vol. I8 pp. 97-II7.

Ribeiro, A. 20r6a. Archaeology will be just Fine. Archaeological Dialogues. Vol. 23 pp. I $46-\mathrm{I} 5 \mathrm{I}$.

Ribeiro, A. 20I6b. Against Object Agency: A Counterreaction to Sørensen's 'Hammers and Nails'. Archaeological Dialogues. Vol. 23 pp. 229-235.

Serres, M. 2007. The Parasite. First published 1980. Translated by Schehr, L.R. Minneapolis: University of Minnesota Press.

Shanks, M. I990. Conclusion: Reading the Signs: Responses to Archaeology after Structuralism. In: Bapty, I. \& Yates, T. (eds). Archaeology After Structuralism: Post-structuralism and the Practice of Archaeology, pp. 294-3 Io. London: Routledge.

Sherratt, A. I989. V. Gordon Childe: Archaeology and Intellectual History. Past \& Present. Vol. I25 pp. I5I-I85.

Sherratt, A. I993. The Relativity of Theory. In: Yoffee, N. \& Sherratt, A. (eds). Archaeological Theory: Who sets the Agenda?, pp. II9-I30. Cambridge: Cambridge University Press.

Solnit, R. 2007. Storming the Gates of Paradise: Landscapes for Politics. Berkeley: University of California Press.

Stewart, K. I996. A Space on the Side of the Road: Cultural Poetics in an 'Other' America. Princeton (NJ): Princeton University Press.

Stewart, K. 2008. Weak Theory in an Unfinished World. Journal of Folklore Research. Vol. 45 pp. 7 I -82.

Swedish Foundations' Starting Grant. 2018. http://startinggrant.se/the-grant/ [Accessed 16 July 2018].

Sørensen, M.L.S. 1984. Changing Images of Archaeology: South Scandinavian Archaeology I8I8 to I978. Archaeological Review from Cambridge. Vol. 3 pp. 38-47.

Tilley, C. 1994. A Phenomenology of Landscape: Places, Paths and Monuments. Oxford: Berg.

Trigger, B.G. 2006. A History of Archaeological Thought. Cambridge: Cambridge University Press.

Vander Linden, M. 20I7. Reaction to a Reactionary Text. Norwegian Archaeological Review. Vol. 50 pp. I27-I29.

Witmore, C.L. 20I4. Archaeology and the New Materialisms. Journal of Contemporary Archaeology. Vol. I pp. 203-224.

Wylie, A. 20I7. Representational and Experimental Modeling in Archaeology. In: Magnani, L. \& Bertolotti, T. (eds). Springer Handbook of Model-Based Science, pp. 989-I002. New York: Springer. 